\title{
A Systematic Review on the Analytical Techniques for the Quantification of Piracetam
}

\section{Arijit Dutta and Mukthinuthalapati Mathrusri Annapurna*}

GITAM Institute of Pharmacy, GITAM (Deemed to be University), Visakhapatnam, India

*Corresponding Author: Mukthinuthalapati Mathrusri Annapurna, GITAM Institute of Pharmacy, GITAM (Deemed to be University), Visakhapatnam, India.
Received: April 15, 2021

Published: June 15, 2021

(C) All rights are reserved by Arijit Dutta and

Mukthinuthalapati Mathrusri Annapurna.

\section{Abstract}

Piracetam is a cyclic analogue of $\gamma$-amino butyric acid which is an inhibitory neurotransmitter. Piracetam is used as a nootropic agent. Much of research work has been done on Piracetam regarding the synthesis, pharmacology, mechanism of actions etc. but in the present article the authors have focused only on the analytical techniques so far published for the estimation of Piracetam in biological fluids as well as pharmaceutical formulations in the literature and these analytical methods were thoroughly reviewed in a systematic manner by considering the analytical instruments used by different authors and some of the validation parameters.

Keywords: Piracetam; Alzheimer's Disease; Myoclonus

\section{Introduction}

Piracetam, chemically is 2-oxo-1-pyrrolidine acetamide is a prototype nootropic agent used clinically for the treatment of memory impairment in aged patients, alcoholism, epilepsy, Alzheimer's disease, dementia etc. [1-4]. Piracetam has a molecular weight $142.156 \mathrm{~g} / \mathrm{mol}$ and molecular formula $\mathrm{C}_{6} \mathrm{H}_{10} \mathrm{~N}_{2} \mathrm{O}_{2}$. Piracetam is soluble in methanol, ethanol, DMSO and water. Piracetam has a pKa value 15.67. UK has approved the license for Piracetam even for the treatment of myoclonus. Myoclonus is an unexpected muscle spasm (Muscle jerks) which may involve a single muscle or group of muscles and the movements are involuntary and cannot be controlled. Piracetam is also used to increase cognitive impairment [5].

Piracetam is available as tablet, injection, syrup and capsule with brand names Neurocetam (Micro Labs Ltd), Perceptal (Pulse Pharmaceuticals Pvt Ltd), Cerecetam (Intas Pharmaceuticals Ltd.),

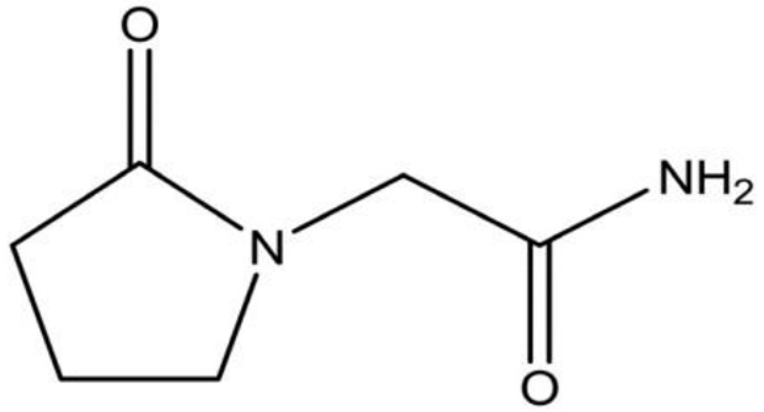

Figure 1: Chemical structure of Piracetam.

Nirocet (Bondane Pharma), Alcetam (Alkem Laboratories), Normenta (Ipca Laboratories Ltd), Nootropil (UCB Pharma Limited) 
etc. with label claim 200, 400, 500, $800 \mathrm{mg}$ in India. Piracetam is available in combination with Citicoline, Cinnarizine, Levetiracetam, Brivaracetam, and Carbamazepine etc. In the present study the authors have reviewed exclusively the analytical methods developed for the quantification of Piracetam in biological samples as well as pharmaceutical dosage forms.

\section{Discussion}

Most of the analytical method were established basing on the chromatographic technique as it takes less time to quantify the drug either in pharmaceutical formulations or in biological fluids. Bhowmick., et al. [6] have developed a validated first derivative spectrophotometric method using methanol for Piracetam pharmaceutical formulations and API in which the $\lambda_{\max }$ was reported as $214 \mathrm{~nm}$ and in this method the linearity was observed over the concentration range 10-80 $\mu \mathrm{g} / \mathrm{ml}$. Karamancheva and Staneva [7] have determined the possible impurities in Piracetam using FTIR spectroscopy and a capillary electrophoresis method was developed in human plasma by Lamparczyk [8] in which the wavelength was chosen at $200 \mathrm{~nm}$ and the linearity observed was 4-24 $\mu \mathrm{g}$ / ml. The impurities of Piracetam were estimated by Ovalles., et al. [9] using TLC and densitometry in which the mobile phase was a mixture consisting of pentyl acetate: ethyl acetate: ethanol: glacial acetic acid (10:10:9:1) and the detection was carried using Gibb's reagent-ammonia vapor. Lengyel., et al. and Alebic-Kolbah., et al. developed gas chromatographic techniques for the determination of Piracetam in human and rat plasma [10] and serum [11] respectively.

Kapendra Sahu., et al. established two stability indicating UPLC and HPLC methods [12] using two different columns Acquity UPLC BEH C18 and Phenomenex C18 columns respectively with two different mobile phases acetonitrile: water (25:75) and acetonitrile: $10 \mathrm{mM}$ ammonium acetate (pH 5.0) (20: 80) mixture and the two method were compared. In both UPLC and HPLC methods BeerLambert's law was obeyed over the concentration range $10-50$ $\mu \mathrm{g} / \mathrm{ml}$. Ardhani DwiLestari., et al. used Lichrospher ${ }^{\circledR}$ (100 RP-18) column methanol: water (5: 95) as mobile phase with detection at $215 \mathrm{~nm}$ for the RP-HPLC method [13]. But in this method the linearity was very narrow and is found to be $0.005-0.1 \mu \mathrm{g} / \mathrm{ml}$. Arayne., et al. developed liquid chromatographic method for the simultaneous determination of Piracetam and its four impurities by RP-HPLC with UV detection at $206 \mathrm{~nm}$ with a very narrow lin- earity range $0.05-10 \mu \mathrm{g} / \mathrm{ml}$. A mixture of $0.02 \%$ tri ethyl amine: acetonitrile (85:15) was used by adjusting the $\mathrm{pH}$ to 6.5 with ortho phosphoric acid with C18 Nucleosil column [14]. Piracetam was estimated by liquid chromatography technique by Louchahi., et al. [15] using methanol: water (5: 95) as mobile phase in human plasma and urine. The assay was carried out by liquid-liquid extraction using hexane-2-propanol at pH 9.2 and the liquid chromatographic method was performed on isocratic mode with UV detection at 206 $\mathrm{nm}$. The method has shown linearity response over the concentration 3 - $40 \mathrm{mg} / \mathrm{l}$ and 100 - $2000 \mathrm{mg} / \mathrm{l}$ in human plasma and urine respectively [15]. Augustin Curticapean and Silvia Imre [16] established a validated HPLC method on gradient mode for the determination of Piracetam in human plasma using Aq. 0.01\% $\mathrm{HClO}_{4}$ : Acetonitrile: Methanol as mobile phase and a linearity of 5 - $80 \mu \mathrm{g} /$ $\mathrm{ml}$ was observed. This experiment was conducted on plasma which was a supernatant layer obtained after proteins precipitation with perchloric acid and they have also proved that Piracetam was stable in plasma for about 4 weeks at $-20^{\circ} \mathrm{C}$ and for 36 hours at $20^{\circ} \mathrm{C}$ in the supernatant after the protein precipitation.

Doheny., et al. [17] developed a specific HPLC method for the estimation of Piracetam using only $25 \mu \mathrm{l}$ of plasma and $10 \mu \mathrm{l}$ of cerebrospinal fluid in presence of internal standard i.e. $\alpha$-ethyl-2oxo-1 -pyrrolidine acetamide and the linearity was observed over the concentration range $4-256 \mu \mathrm{g} / \mathrm{ml}$. The authors performed the pharmacokinetic profile using the typical plasma and cerebrospinal fluid of Piracetam after intra peritoneal administration of Piracetam to a single male Sprague-Dawley rat.

Nalbandian., et al. [18] performed the chromatographic study on the methanol extracts of serum and aqueous humor using Bondapak C18 and a mobile phase mixture consisting of methanol: $0.1 \mathrm{M} \mathrm{KH}_{2} \mathrm{PO}_{4}$ solution where the $\mathrm{pH}$ was adjusted to 4.8 with 0.1 $\mathrm{M} \mathrm{HCl}$ and the linearity was shown as 5 - $15 \mathrm{nmol}$. A LC-MS/MS method was developed for the pharmacokinetic study of Piracetam in rat plasma [19] using acetonitrile: 1\% formic acid (10:90) as mobile phase in presence of an internal standard Oxiracetam. Protein precipitation was achieved with trichloro acetic acid (5\%) and the linearity was observed over the concentration range $0.1-20 \mu \mathrm{g} /$ $\mathrm{ml}$. Different analytical methods were established by different authors for the quantification of Piracetam in pharmaceutical formulations as well as the biological fluids. Table 1 highlights some of the important parameters observed during this systematic review. 


\begin{tabular}{|c|c|c|c|}
\hline Reagent/Column/Mobile phase (v/v) & $\begin{array}{l}\text { Linearity } \\
(\mu \mathrm{g} / \mathrm{ml})\end{array}$ & Comment & Ref \\
\hline Methanol (First derivative spectroscopy) & $10-80$ & $\lambda_{\max }=214 \mathrm{~nm}$ & [6] \\
\hline FTIR spectroscopy & $0.1-1.3 \mathrm{mg} / \mathrm{mg}$ & Impurities & [7] \\
\hline Capillary electrophoresis & $4-24$ & $\begin{array}{l}\qquad \lambda=200 \mathrm{~nm} \\
\text { Human plasma }\end{array}$ & {$[8]$} \\
\hline $\begin{array}{l}\text { TLC and Densitometry } \\
\text { Pentyl acetate: Ethyl acetate: Ethanol: Glacial acetic acid } \\
(10: 10: 9: 1) \\
\text { Detection: Gibb's reagent-Ammonia vapor }\end{array}$ & - & $\begin{array}{l}\text { Impurities } \\
\text { Sample: } 210 \mathrm{~nm} \text {; } \\
\text { Reference: } 230 \mathrm{~nm}\end{array}$ & {$[9]$} \\
\hline Gas Chromatography & $\begin{array}{l}0.1-100 / 0.5 \mathrm{ml} \\
\text { plasma }\end{array}$ & $\begin{array}{l}\text { Human plasma and } \\
\text { Rat plasma }\end{array}$ & [10] \\
\hline Gas Chromatography & - & Serum & [11] \\
\hline $\begin{array}{l}\text { UPLC: Acquity UPLC BEH C18/Acetonitrile: Water (25:75) } \\
\text { HPLC: Column-Phenomenex C18/ } \\
\text { Acetonitrile: } 10 \text { mM Ammonium acetate (pH 5.0) (20: 80) }\end{array}$ & $10-50$ & $\begin{array}{c}\text { UPLC } \\
\text { Stability-indicating } \\
\text { HPLC } \\
\text { (Isocratic mode) }\end{array}$ & [12] \\
\hline Lichrospher ${ }^{\circledR}$ (100 RP-18) column/ Methanol: water (5: 95) & $0.005-0.1$ & $\begin{array}{c}\text { HPLC } \\
215 \mathrm{~nm} \\
\end{array}$ & [13] \\
\hline $\begin{array}{l}\text { C18 Nucleosil/0.02 \% Tri ethyl amine: Acetonitrile (85:15) } \\
\text { (pH adjusted to } 6.5 \text { with ortho phosphoric acid) }\end{array}$ & $0.05-10$ & $\begin{array}{c}\text { HPLC } \\
205 \mathrm{~nm}\end{array}$ & [14] \\
\hline Hibar LiChrosorb RP-18/Methanol: water (5: 95) & $\begin{array}{c}3-40 \\
100-2000\end{array}$ & $\begin{array}{l}\text { HPLC } \\
\text { Human plasma and Urine } \\
206 \mathrm{~nm}\end{array}$ & [15] \\
\hline $\begin{array}{l}\text { RP-18 LiChroSpher } 100 / \text { Aq. } 0.01 \% \mathrm{HClO}_{4} \text { : Acetonitrile: Metha- } \\
\text { nol (Gradient mode) }\end{array}$ & $5-80$ & $\begin{array}{c}\text { HPLC } \\
\text { Human plasma } 200 \mathrm{~nm}\end{array}$ & [16] \\
\hline $\begin{array}{l}215 \text { nm Spherisorb S5CN/Acetonitrile: Water (98:2) } \\
\boldsymbol{\alpha} \text {-ethyl-2-oxo-1 -pyrrolidine acetamide (Internal standard) }\end{array}$ & 4- 256 & $\begin{array}{l}\text { HPLC } \\
\text { Plasma or Cerebrospinal } \\
\text { fluid }\end{array}$ & [17] \\
\hline $\begin{array}{l}\text { Bondapak C18/Methanol: } 0.1 \mathrm{M} \mathrm{KH}_{2} \mathrm{PO}_{4} \\
\text { (pH adjusted } 4.8 \text { with } 0.1 \mathrm{M} \mathrm{HCl} \text { ) }\end{array}$ & $5-15 \mathrm{nmol}$ & $\begin{array}{l}\text { HPLC } \\
\text { Rabbits serum and Aqueous } \\
\text { humor } 208 \mathrm{~nm}\end{array}$ & [18] \\
\hline $\begin{array}{l}\text { Zorbax SB-Aq/Acetonitrile: 1\% Formic acid (10:90) } \\
\text { Oxiracetam (Internal standard) }\end{array}$ & $0.1-20$ & $\begin{array}{l}\text { LC-MS/MS } \\
\text { Rat plasma }\end{array}$ & [19] \\
\hline
\end{tabular}

Table 1: Review of analytical techniques for the estimation of Piracetam. 


\section{Conclusions}

The present review helps the readers to understand the existing analytical techniques so far proposed for the estimation of Piracetam.

\section{Bibliography}

1. British Pharmacopoeia 2003. "The Stationary Office". 2(2003): 1497-1498.

2. Parfitt K. "Martindale The complete drug reference". 32nd Edition; Pharmaceutical Press: London (1999): 1619.

3. Noorbala AA., et al. "Piracetam in the treatment of schizophrt nia: implication for the glutamate hypothesis of schizophrs nia". Journal of Clinical Pharmacy and Therapeutics 24 (1999,. 369-374.

4. France Pharmacopoeia, IX(1991).

5. Suelen AN., et al. "Analgesic activity of Piracetam: Effect on cytokine production and oxidative stress". Pharmacology Biochemistry and Behavior 105 (2013): 183-192.

6. Bhowmick Anindita A., et al. "Analytical Method Development and Validation for Piracetam as Bulk and in Pharmaceutical Formulation". International Journal of PharmTech Research 2. (2010): 201-204.

7. Karamancheva I and Staneva T. "Determination of possib] impurities in Piracetam using FTIR spectroscopy". Journal of Pharmaceutical and Biomedical Analysis 21.6 (2000): 11611169.

8. Lamparczyk H., et al. "Determination of Piracetam in human plasma by capillary electrophoresis". Journal of Chromatography B: Biomedical Sciences and Applications. 692.2 (1997): 483-487.

9. Ovalles JF., et al. "Determination of Piracetam and its impurities by TLC". Journal of Pharmaceutical and Biomedical Analysis 23.4 (2000): 757-761.

10. Lengyel J., et al. "New validated gas-chromatographic method for Piracetam determination in plasma". Pharmaceutical Sciences 3 (1997): 455-459.
11. Alebic-Kolbah $\mathrm{T}$ and Hirsl-Starcevic S. "Determination of Piracetam in serum by gas chromatography". Journal of Chromatography 526 (1990): 556-561.

12. Kapendra Sahu., et al. "Establishment of inherent stability on Piracetam by UPLC and development of a validated stabilityindicating method". Arabian Journal of Chemistry 10 (2017): S576-S582.

13. Ardhani Dwi Lestari., et al. "HPLC determination of Piracetam in tablets; Validation of the method". Journal of Liquid Chromatography and Related Technologies 28.9 (2005): 1407-1416.

14. Arayne MS., et al. "Simultaneous determination of Piracetam and its four impurities by RP-HPLC with UV detection". Journal of Chromatographic Science 48.7 (2010): 589-594.

15. Louchahi K., et al. "Determination of Piracetam in human plasma and urine by liquid chromatography". Journal of Chromatography B Biomed 663.2 (1995): 385-389.

16. Augustin Curticapean and Silvia Imre . "New validated method for Piracetam HPLC determination in human plasma". Journal of Biochemical and Biophysical Methods 69. 3 (2007): 273-281.

17. Doheny $\mathrm{MH}$., et al. "A high-performance liquid-chromatographic microanalytical procedure for the rapid estimation of Piracetam in plasma or cerebrospinal fluid". Journal of Pharmacy and Pharmacology 48.5 (1996): 514-516.

18. RM Nalbandian., et al. "Liquid-chromatographic quantification of Piracetam". Clinical Chemistry 29.4 (1983): 664-666.

19. Xianqin Wang., et al. "Determination of Piracetam in rat plasma by LC-MS/MS and its application to Pharmacokinetics". Biomedical Chromatography 24.10 (2010): 1108-1112.

\section{Volume 5 Issue 7 July 2021 \\ (C) All rights are reserved by Arijit Dutta and Mukthinuthalapati Mathrusri Annapurna.}

